\title{
Śmierć i Upadek: dlaczego teistyczny ewolucjonizm nie łagodzi problemu zła
}

Według kreacjonistów młodej i starej Ziemi ludzie noszący obraz Boga zostali stworzeni z niczego. ${ }^{1}$ Innymi słowy, Bóg, stwarzając nas, zrobił coś radykalnie nowego - nie wyłoniliśmy się z wcześniej istniejących organizmów. W świetle tego poglądu w pełni funkcjonujące hominidy, mające całkowicie ludzkie ciała, lecz pozbawione obrazu Boga, nigdy nie istniały. Natomiast według większości teistycznych ewolucjonistów przedstawiciele rzędu naczelnych, będący naszymi przodkami, w ciągu kilku milionów lat przekształcili się ewolucyjnie w hominidy posiadające całkowicie ludzkie ciała. Co wydarzyło się później? Lekarz Paul Brand znajduje możliwą odpowiedź w Księdze Rodzaju 2:7, gdzie czytamy: „wtedy to Pan Bóg ulepił człowieka z prochu ziemi i tchnął w jego nozdrza tchnienie życia, wskutek czego stał się człowiek istotą żywą" (BT). Zastanawiając się nad tym fragmentem, Brand napisał:

Gdy czytałem ten werset jako dziecko, wyobrażałem sobie Adama leżącego na ziemi, w pełni ukształtowanego, lecz jeszcze nie żywego, oraz Boga pochylającego się nad nim i robiącego mu sztuczne oddychanie metodą usta-usta. Teraz przedstawiam sobie

*William A. Dembsкi, „Death and the Fall: Why Theistic Evolution Does Nothing to Mitigate the Problem of Evil", w: Jay W. Richards (ed.), God and Evolution: Protestants, Catholics, and Jews Explore Darwin's Challenge to Faith, Discovery Institute Press, Seattle 2010, s. 91102. Z języka angielskiego za zgodą Autora i Wydawnictwa przełożył: Dariusz Sagan.

${ }^{1}$ Niniejszy artykuł został zaadaptowany z mojej książki: William A. Dembsкi, The End of Christianity: Finding a Good God in an Evil World, Broadman and Holman, Nashville 2009. 
tę scenę inaczej. Uznaję, że Adam był już żywy w sensie biologicznym — inne zwierzęta nie potrzebowały specjalnego wdmuchnięcia tlenu, azotu i dwutlenku węgla, by móc zacząć oddychać, dlaczego więc miałby potrzebować tego człowiek? Teraz tchnienie Boga symbolizuje dla mnie duchową rzeczywistość. Wyobrażam sobie Adama jako żywego, lecz obdarzonego witalnością jedynie zwierzęcą. Następnie wyobrażam sobie, jak Bóg tchnął weń nowego ducha i napełnił go Swoim obrazem. Adam stał się żyjącą duszą, nie zaś tylko żyjącym ciałem. Obraz Boga nie jest układem komórek skóry czy jakimś fizycznym kształtem, lecz uzyskanym poprzez tchnienie duchem. ${ }^{2}$

Zatem hominidy, które wyewoluowały z ssaków naczelnych, z początku nie miały pierwiastka duchowego - przypuszczalnie obejmującego zdolności poznawcze i moralne - wymaganego, by nosić obraz Boga. ${ }^{3}$ Potem, w jakimś określonym momencie, otrzymały one obraz Boga i w pełni stały się ludźmi.

Przy założeniu, że ludzie wyewoluowali pod Boskim kierownictwem, Bóg musiał w pewnym momencie przekształcić ich $\mathrm{w}$ działające racjonalnie i moralnie istoty uczynione na Jego obraz. Czy jednak taka transformacja jestestwa i świadomości jest zgodna z teorią ewolucji biologicznej, w rozumieniu przyjmowanym przez większość naukowców? Tak i nie. Genetyk ewolucyjny Jerry Coyne definiuje teorię ewolucji biologicznej w następujący sposób:

Istnieje tylko jedna aktualnie przyjmowana teoria ewolucji i głosi ona, że organizmy ewoluowały stopniowo w czasie i rozdzielały się na różne gatunki, zaś głównym motorem zmiany ewolucyjnej był dobór naturalny. Oczywiście pewne szczegóły tych procesów nie są ustalone, jednak pośród biologów panuje jednomyślność co do kluczowych twierdzeń. ${ }^{4}$

Jest to standardowa definicja teorii ewolucji biologicznej — podręcznikowa ortodoksja - chociaż Coyne nie wspomina tu o losowej zmienności. Zgodnie z ortodoksyjnym poglądem teoria ewolucji biologicznej wspiera się na dwóch

\footnotetext{
${ }^{2}$ Phillip Yancey and Paul Brand, In His Image, Zondervan, Grand Rapids 1984, s. 22.

${ }^{3}$ Denis Alexander pisze: „Bycie anatomicznie współczesnym człowiekiem stanowiło konieczny, lecz nie wystarczający warunek bycia żywym pod względem duchowym” (Denis Alexander, Creation or Evolution: Do We Have to Choose?, Monarch Books, Oxford 2008, s. 237).

${ }^{4}$ Jerry Coyne, „Don't Know Much Biology”, Edge 6 June 2007, http://www.edge.org/conver sation/don-39t-know-much-biology (24.08.2013).
} 
filarach: uniwersalnej wspólnocie pochodzenia, czyli historycznym twierdzeniu, że wszystkie organizmy wywodzą się od wspólnego przodka, oraz mechanizmie darwinowskim, to jest teoretycznym twierdzeniu, że dobór naturalny działający na rezultaty losowej zmienności odpowiada za biologiczną dywersyfikację.

Definicja Coyne'a jest dość ogólnikowa, a także wskazuje, że ,pewne szczegóły [...] nie są ustalone", jest zatem możliwe, że Bóg posłużył się tak rozumianą ewolucją, by obdarzyć hominidy poznawczymi, moralnymi i innymi zdolnościami niezbędnymi do noszenia obrazu Boga. I być może Bóg przekształcił ludzką świadomość, zdolność moralną i tym podobne, nie dokonując cudu w tradycyjnym sensie. Na przykład obraz Boga może być emergentną własnością ludzkiego mózgu, który osiągnął pewien stopień złożoności. Zakłada się tu monizm, w świetle którego człowiek jest istotą zasadniczo materialną (lecz również stworzeniem Boga). ${ }^{5}$ Ewentualnie być może z podaną przez Coyne’a charakterystyką teorii ewolucji biologicznej zgodny jest dualizm, w myśl którego człowiek stanowi zasadniczo jedność materii i ducha. ${ }^{6}$ Niewykluczone na przykład, że Bóg mógł „dodać” duszę do ciała ludzkiego, by odcisnąć na nim Swój obraz. Zwolenniczką stanowiska monistycznego jest Nancey Murphy, ${ }^{7}$ zaś dualistycznego — Francis Collins. ${ }^{8}$ Oba stanowiska afirmują zarówno teorię ewolucji, jak i wiarę chrześcijańską.

\footnotetext{
${ }^{5}$ Por. artykuły opublikowane w: Warren S. Brown, Nancey Murphy, and H. Newton Malony (eds.), Whatever Happened to the Soul? Scientific and Theological Portraits of Human Nature, Augsburg Fortress, Minneapolis 1998; oraz książkę: Peter VAn Inwagen, Material Beings, Cornell University Press, Ithaca 1990.

${ }^{6}$ Por. Mario Beauregard and Denyse O'Leary, The Spiritual Brain: A Neuroscientist's Case for the Existence of the Soul, HarperOne, San Francisco 2007; Jeffrey Schwartz and Sharon Begley, The Mind and the Brain: Neuroplasticity and the Power of Mental Force, Regan Books, New York 2002.

${ }^{7}$ Por. Nancey MurPhy, „Nonreductive Physicalism: Philosophical Issues”, w: Brown, MurPHy, and Malony (eds.), Whatever Happened to the Soul..., s. 127-148.

${ }^{8}$ „Ludzie jednakże są zarazem istotami wyjątkowymi, ponieważ ich postępowanie przeciwstawia się zasadom wynikającym z teorii ewolucji, co wskazuje na ich duchową naturę. Przejawem tego jest prawo moralne (umiejętność odróżniania dobra od zła) oraz poszukiwanie Boga, które charakteryzuje wszystkie ludzkie kultury na przestrzeni całej naszej historii" (Francis S. Collins, Język Boga. Kod życia - nauka potwierdza wiarę, przeł. Małgorzata Yamazaki, Świat Książki, Warszawa 2008, s. 163).
} 
Wszystko to jest dość mgliste i ma charakter spekulatywny, ale być może Coyne pozostawił Bogu wystarczające pole manewru, by mógł obdarzyć człowieka Swoim obrazem. Niemniej takie stanowiska są niezgodne z poglądami większości darwinistów, którzy przeczą istnieniu jakiejkolwiek fundamentalnej, jakościowej nieciągłości między świadomością i różnymi zdolnościami człowieka a ich przypuszczalnych przodków z rzędu naczelnych. To zaprzeczenie ma zresztą znakomity rodowód, ponieważ sam Karol Darwin odrzucał istnienie zasadniczego rozdziału między ludzkimi zdolnościami poznawczymi i moralnymi a tymi posiadanymi przez pozostałe zwierzęta. W O pochodzeniu czlowieka napisał on:

[...] różnica między umysłem człowieka i wyższych zwierząt, mimo że jest wielka, jest różnicą stopnia a nie rodzaju. Widzieliśmy, że wrażenia i odczucia, różne uczucia i zdolności, jak miłość, pamięć, zdolność do skupiania uwagi, do rozumowania, ciekawość, naśladownictwo itp., którymi szczyci się człowiek, można stwierdzić w zalążku, a nawet niekiedy zupełnie dobrze rozwinięte u niższych zwierząt. ${ }^{9}$

Co więcej, nie jest to jedynie ateistyczny dodatek do teorii. Wręcz przeciwnie, wielu teistycznych ewolucjonistów zgadza się z Darwinem, że między ludźmi a resztą świata zwierząt pod każdym względem zachodzi ciągłość. Na przykład w książce Saving Darwin [W obronie Darwina] Karl Giberson stwierdza:

Jeśli zaakceptujemy cały ewolucjonistyczny obraz pochodzenia człowieka, staniemy przed problemem ludzkiej wyjątkowości. Zgodnie z obrazem historii naturalnej ukazywanym przez współczesną naukę człowiek wyewoluował powoli i niepostrzeżenie z żyjących wcześniej, prostszych stworzeń. Żaden z naszych atrybutów — inteligencja, postawa wyprostowana, zmysł moralny, przeciwstawne kciuki, zdolność posługiwania się językiem — nie pojawił się nagle. Każda nasza niezwykła zdolność musiała pojawiać się stopniowo i była obecna częściowo, jako antycypacja, u naszych przodków z rzędu naczelnych. Kryje się tu prowokacyjna sugestia, że zwierzęta, zwłaszcza wyższe ssaki naczelne, powinny posiadać rozpoznawalny zmysł moralny różniący się jedynie ilościowo od tego, jakim dysponują ludzie. I nie ma się co dziwić, że wyniki najnowszych badań potwierdzają ten pogląd. ${ }^{10}$

\footnotetext{
${ }^{9}$ Karol DARwIN, O pochodzeniu czlowieka. Dziela wybrane, t. IV, przeł. Stanisław Panek, Biblioteka Klasyków Biologii, Państwowe Wydawnictwo Rolnicze i Leśne, Warszawa 1959, s. 80 .

${ }^{10}$ Karl W. Giberson, Saving Darwin: How to Be a Christian and Believe in Evolution,
} 
Niestety, jak uzmysławia niedawny skandal Climategate, ${ }^{11}$ wyniki badań naukowych można tak zmanipulować, by potwierdzały dowolny wniosek. Giberson przechodzi dalej do argumentacji przeciwko koncepcji wyjątkowości człowieka, opierając się na badaniach nad ssakami naczelnymi. W książce The Design of Life [Projekt życia] Jonathan Wells i ja argumentujemy na rzecz wyjątkowości człowieka na podstawie lingwistyki, matematyki i psychologii poznawczej. ${ }^{12}$ Niech czytelnik zdecyduje, kto z nas oferuje lepsze argumenty. ${ }^{13}$ W ramach koncepcji wyjątkowości człowieka przyznaje się, że między ludźmi a innymi naczelnymi zachodzą istotne podobieństwa. Podkreśla się jednak, że istnieją też daleko idące różnice, szczególnie w zakresie zdolności poznawczych i moralnych, i że są to różnice rodzajowe, nie zaś, jak utrzymywał Darwin, a za nim współcześni darwiniści, zaledwie różnice stopnia. ${ }^{14}$

HarperOne, San Francisco 2008, s. 13 [wyróżnienie w oryginale].

${ }^{11}$ Por. A.W. Montford, The Hockey Stick Illusion: Climategate and the Corruption of Science, Stacey, London 2010.

${ }^{12}$ Por. William A. Dembski and Jonathan Wells, The Design of Life: Discovering Signs of Intelligence in Biological Systems, Foundation for Thought and Ethics, Dallas 2008, rozdz. 1, poświęcony problemowi pochodzenia człowieka.

${ }^{13}$ Jest to oczywiście obszerny temat i prace Gibersona oraz moja stanowią jedynie czubek góry lodowej. W literaturze ewolucjonistycznej zdecydowanie przeważa argumentacja przeciwko wyjątkowości człowieka. Przeciwny pogląd prezentuje cytowana w następnym przypisie książka Mortimera Adlera, jak również: Benjamin WiKer, Moral Darwinism: How We Became Hedonists, InterVarsity, Downers Grove 2002; C. Stephen Evans, Preserving the Person: A Look at Human Sciences, Regent College Publishing, Vancouver 1994; David Berlinski, Szatańskie urojenie. Ateizm i jego pretensje naukowe, przeł. Dominika Cieśla-Szymańska, Prószyński i S-ka, Warszawa 2009.

${ }^{14}$ Podział na różnicę rodzajową i różnicę stopnia, zwłaszcza w odniesieniu do zagadnienia wyjątkowości człowieka, objaśniony został w książce: Mortimer AdLer, The Difference of Man and the Difference It Makes, Fordham University Press, New York 1993. Książka ta, choć pierwotnie opublikowana w 1967 roku, jest lekturą niezbędną dla każdego, kto interesuje się proble mem wyjątkowości człowieka. Na samym jej początku znajdujemy eksperyment myślowy dotyczący tego, co by się stało, gdyby możliwe było krzyżowanie się człowieka i małp człekokształt nych.

Czterdzieści lat później Richard Dawkins zaproponował przełamanie bariery gatunkowej poprzez „skuteczne skrzyżowanie człowieka z szympansem” (Richard DAwkins, „Breaking the Species Barrier”, Edge January 2009, http://www.edge.org/q2009/q09_16.html [24.08.2013]). Dawkins kontynuuje: „Nawet gdyby ta hybryda była bezpłodna, jak muł, wstrząsy, które prze szłyby po społeczeństwie, miałyby zbawienny skutek. To dlatego pewien wybitny biolog uznał tę 
Skrajny darwinizm Gibersona prowadzi go do odrzucenia poglądu, że w jakimś konkretnym momencie ewoluujące hominidy mogły zostać przekształcone przez Boga na Jego obraz: „Można wierzyć na przykład, że w jakimś punkcie historii ewolucyjnej Bóg «wybrał» dwie osoby z grupy ewoluujących «ludzi», nadał im Swój obraz i umieścił ich w Raju, który szybko zniszczyli, popełniając grzech. Takie rozwiązanie jest jednak niezadowalające, sztuczne i z pewnością nie taka była intencja autora Księgi Rodzaju". ${ }^{15}$ Jeżeli już jednak interesuje nas, co miał na myśli autor Księgi Rodzaju, to prawdopodobnie nie powinniśmy sądzić, że jest tam mowa o teorii ewolucji. Jeśli autor Księgi Rodzaju 1:21 i 1:25 stwierdził, że organizmy zostały stworzone „według ich rodzajów”, to trudno uznać, że miał na myśli ewolucyjną płynność wszystkich gatunków. Niemniej, jeśli ktoś zdecyduje się odczytywać Księgę Rodzaju na modłę ewolucjonistyczną, to przyjęcie idei odrębnego przekształcenia jestestwa lub świadomości na obraz Boga staje się koniecznością - to znaczy pod warunkiem, że naprawdę chce się zachować ideę Upadku. Musiał przecież istnieć jakiś stan, względem którego pierwsi ludzie upadli.

Giberson, niestety, nie chce zachować idei Upadku. Zacytowany przed chwilą fragment książki Saving Darwin występuje w części zatytułowanej „Dissolving the Fall” [Wyeliminowanie problemu Upadku]. Giberson odrzuca

możliwość za najbardziej niemoralny eksperyment naukowy, jaki jest w stanie sobie wyobrazić: odmieniłby wszystko!"

Dawkins uznaje taki eksperyment nie za niemoralny, lecz, gdyby się powiódł, wyzwalający: „W naszej etyce i polityce zakłada się, przeważnie nie zadając żadnych pytań czy nie przeprowadzając poważnej dyskusji, że rozdział między człowiekiem a «zwierzęciem» jest absolutny”. We dług Dawkinsa „człekopans” (humanzee) obalałby ideę wyjątkowości człowieka i niszczył cały opierający się na niej judeochrześcijański system etyczny, co bardzo by go ucieszyło. Czy teistyczni ewolucjoniści, jak Karl Giberson, są gotowi podążyć śladem Dawkinsa? Czy mogą odmówić człowiekowi wyjątkowości? Dlaczego by nie?

${ }^{15}$ Giberson, Saving Darwin..., s. 12. C.S. Lewis znał - i odrzucił - stanowisko reprezentowane przez Gibersona. Według Lewisa człowiek sceptyczny wobec tradycyjnych doktryn teologicznych „naturalnie ze zniecierpliwieniem słucha naszych szczegółowych rozwiązań trudności i naszej obrony przeciw poszczególnym zarzutom. Im bardziej pomysłowi jesteśmy w takich rozwiązaniach i obronie, tym bardziej mu się wydajemy przewrotnymi. [...] doszedłem do przekonania, że stanowisko to wynika z zupełnego nieporozumienia" (Clive Staples Lewis, Cudy. Wprowadzenie ogólne, przeł. Stanisław Pacuła, Instytut Wydawniczy „Pax”, Warszawa 1958, s. 104$105)$ 
każdą tradycyjną koncepcję Upadku. ${ }^{16}$ Jego ujęcie jest uproszczone i heterodoksyjne. $\mathrm{W}$ jego mniemaniu istotą grzechu jest egoizm. A tak się składa, że „egoizm”, według Gibersona, ,jest motorem procesu ewolucji”. ${ }^{17}$ Mówiąc wprost, jesteśmy samolubni, ponieważ ewolucja jest samolubna, a my jesteśmy wytworem ewolucji. Dla niego zbawienie jest więc wykroczeniem poza naszą ewolucyjną przeszłość. Natomiast w świetle tradycyjnego ujęcia Upadku zostaniemy wybawieni nie od tego, co wytworzyła w nas ewolucja, lecz od tego, co dobrowolnie uczyniliśmy samym sobie, grzesząc przeciwko świętemu Bogu. Tradycyjne stanowisko głosi, że doświadczane przez ludzkość zło jest złem, które ona sama na siebie sprowadziła.

\section{Rozwiązanie problemu zla?}

Wielu teistycznych ewolucjonistów zachwala jednak ten heterodoksyjny element swojego poglądu, ponieważ sądzą oni, że oferuje on lepszą odpowiedź na problem zła niż tradycyjna ortodoksja. W rzeczy samej, większość teistycznych ewolucjonistów coraz częściej argumentuje, że dla teizmu chrześcijańskiego korzystne jest przyjęcie idei, iż Bóg stwarzał pośrednio za pomocą procesów darwinowskich, nie zaś bezpośrednio (dokonując oddzielnych aktów stwórczych). Teistyczni ewolucjoniści martwią się, że idea Boga stwarzającego bezpośrednio uniemożliwia rozwiązanie problemu zła. Taki Bóg byłby odpowiedzialny za wszystkie nieudolne i złe projekty, jakie znajdujemy w przyrodzie. Zastępując projektanta darwinowskim doborem naturalnym, teistyczni ewolucjoniści mogą wszystkie takie projekty zrzucić na karb ewolucji. W ich przekonaniu pozwala to rozwiązać problem zła naturalnego i zapewnić uzasadnienie teizmowi chrześcijańskiemu. ${ }^{18}$

\footnotetext{
${ }^{16}$ Giberson mógłby oponować, że jedynie przedefiniowuje lub rekonceptualizuje Upadek w taki sposób, by zachować jego najważniejsze aspekty historyczne. W jego rekonceptualizacji zupełnie nie da się jednak dostrzec śladów ortodoksyjnego ujęcia Upadku.

${ }^{17}$ Giberson, Saving Darwin..., s. 12.

${ }^{18}$ Taki tok rozumowania, doprowadzony do jego logicznego wniosku, można znaleźć w: Gaymon Bennetr, Martinez J. Hewlett, Ted Peters, and Robert John Russell (eds.), The Evolution of Evil, Vandenhoeck \& Ruprecht, Göttingen, Germany 2008.
} 
Słynny darwinista i były ksiądz katolicki Francisco Ayala posiłkuje się właśnie taką argumentacją: „Największe brzemię zostało zdjęte z ramion wierzących, kiedy zgromadzono przekonujące dowody, że projekt organizmów nie musi być przypisywany bezpośredniemu działaniu Stwórcy, lecz wynika z działania naturalnych procesów”. Według Ayali: „Jeśli twierdzimy, że organizmy i ich części zostały szczegółowo zaprojektowane przez Boga, musimy wyjaśnić niekompetentny plan budowy ludzkiej szczęki, niedogodność dróg rodnych i nasz kiepsko zaprojektowany kręgosłup, z trudem dopasowany do wyprostowanego chodu".

Zgodnie z poglądem Ayali prawomyślni chrześcijanie powinni „docenić darwinowską rewolucję i zaakceptować dobór naturalny jako proces wyjaśniający projekt organizmów, a także dysfunkcje, dziwaczność, okrucieństwo i sadyzm przenikające świat istot żywych. Przypisywanie tego bezpośrednim działaniom Boga urasta do rangi bluźnierstwa”. Oskarżanie chrześcijańskich przeciwników teorii Darwina o bluźnierstwo może wydawać się krokiem zbyt surowym. Ayala próbuje więc złagodzić swoje oskarżenie przyznając, że ludzie przeciwni teorii ewolucji i opowiadający się za koncepcją specjalnego stworzenia „są z pewnością pełni najlepszych intencji i nie chcą być bluźniercami”. Ayala czyni tutaj ustępstwo na rzecz (i jest protekcjonalny względem) intelektualnej słabości, jak on to widzi, tych, którzy kurczowo trzymają się starego, naiwnego kreacjonistycznego poglądu i muszą jeszcze oswoić się z myślą, że teoria ewolucji jest ewidentnie prawdziwa. W każdym razie nie wycofuje on oskarżenia o bluźnierstwo: „tak rzecz wygląda z perspektywy biologa zaniepokojonego pomniejszaniem Boga przez imputowanie mu niekompetencji”. ${ }^{19}$

Odwracając sytuację na niekorzyść koncepcji specjalnego stworzenia, Ayala w istocie obrócił ją o 360 stopni. Sytuacja powraca do punktu wyjścia i Ayala nadal stoi przed problemem, którym chciał obarczyć koncepcję specjalnego stworzenia. Martwi go, że Bóg, który stwarza poprzez bezpośrednią interwencję, musi być odpowiedzialny za wszystkie złe projekty w świecie. Proponuje on w zamian rozwiązanie, że Bóg stwarza świat, w którym to ewolucja (drogą do-

\footnotetext{
${ }^{19}$ Ayala najwyraźniej staje w obronie honoru Boga tylko wtedy, gdy zachwala darwinowską teorię ewolucji. Wszystkie cytaty w tym i poprzednim akapicie pochodzą z: Francisco J. Ayala, Dar Karola Darwina dla nauki i religii, przeł. Piotr Dawidowicz, Wydawnictwa Uniwersytetu Warszawskiego, Warszawa 2009, s. 149.
} 
boru naturalnego i losowej zmienności) tworzy takie projekty. W jaki jednak sposób rozwiązuje to podstawowy problem, że Bóg Stwórca ustanowił warunki, w jakich powstają złe projekty? W pierwszym przypadku Bóg działa bezpośrednio, w drugim - pośrednio. W obu przypadkach na Bogu Stwórcy, jako wszechpotężnym źródle wszechrzeczy, ciąży jednakowa odpowiedzialność.

Nie akceptujemy takiego przeniesienia odpowiedzialności w żadnych innych ważnych sytuacjach, dlaczego więc mielibyśmy zrobić to w tym wypadku? Jaka byłaby różnica, gdyby jakiś bandyta zrobił komuś krzywdę własnymi rękami (czyli stosując środki bezpośrednie) lub gdyby wykorzystał w tym celu agresywnego psa na smyczy (czyli stosując środki pośrednie). Ów bandyta byłby równie odpowiedzialny w obu przypadkach. To samo dotyczy Boga Stwórcy, którzy stwarza bądź bezpośrednio, bądź pośrednio, za pomocą ewolucji. Stworzenie pociąga za sobą odpowiedzialność, która zawsze spoczywa na Stwórcy. To dlatego tak duża część współczesnej teologii ma problem nie tylko z ideą Boga ,interweniującego" w przyrodzie, lecz także z tradycyjną doktryną stworzenia ex nihilo, która źródło przyrody upatruje w Bogu.

Ostatnim krzykiem mody w teologii jest umniejszanie mocy i statusu Boga jako istoty najwyższej tak, by Bóg był zasadniczo ograniczony przez świat i nie mógł być odpowiedzialny za istniejące w nim zło. Dobry przykład stanowi teologia procesu, w ramach której Boga postrzega się jako ewoluującego wraz ze światem, a świat jako mający autonomię wymykającą się zasięgowi Boga (co umożliwia zrzucenie z Boga odpowiedzialności za zło). Oto, jak rozumuje teolog procesu Robert Mesle:

Ponieważ Bóg nie może kontrolować procesu ewolucji, nie ma więc powodu nawet zakładać, że Bóg nakierował ten proces na wytworzenie właśnie nas. Historia ewolucji pełna jest bardziej kluczowych zdarzeń niż jesteśmy w stanie sobie wyobrazić, a Bóg nie może ich kontrolować. Bóg splótł się ze światem w ciągłym tańcu, w którym stale musi On przyjmować decyzje stworzeń i działać na ich podstawie — jakiekolwiek by one nie były. Dobre to czy złe, każda decyzja każdego stworzenia odgrywa rolę w procesie stawania się świata. I Bóg stara się stworzyć coś dobrego z tego, co podsuwa świat. Ewolucja jest więc nieustanną przygodą tak dla Boga, jak dla świata. ${ }^{20}$

\footnotetext{
${ }^{20}$ C. Robert Mesle, Process Theology: A Basic Introduction, Chalice Press, St. Louis 1993, s. 62 .
} 
Moim zdaniem teologia procesu stwarza całe mnóstwo nowych problemów i dlatego nie nadaje się do zastąpienia tradycyjnych doktryn Boga i stworzenia. Dla celów argumentacji przyjmijmy jednak, że rozwiązuje ona problem dysteleologii (złych projektów) będącej wynikiem działania doboru naturalnego. Problem w tym, że Ayala i inni słynni teistyczni ewolucjoniści nie opowiadają się za teologią procesu (lub jakąś inną koncepcją, która umniejsza Boga), lecz za zgodnością w pełni darwinowskiej teorii ewolucji z klasycznym teizmem chrześcijańskim. Mówi się nam: „Jeśli zaakceptujesz teorię ewolucji, to nadal będziesz mógł być dobrym chrześcijaninem". ${ }^{21}$

Ayala nie ma zatem podstaw, by wymagać od wyznawców chrześcijaństwa, aby zrewidowali swoją doktrynę Boga w świetle teorii Darwina. W szczególności nie może wymagać, by ludzie wierzący w Boską wszechmoc i stworzenie ex nihilo skorygowali swoje przekonania tak, by były zgodne z teologią przyjaźniejszą teorii ewolucji. Dla chrześcijan utrzymujących tradycyjną doktrynę stworzenia i uznających mechanizm selekcji i losowej zmienności za Boską metodę stwarzania organizmów problem zła stanowi taką samą trudność jak dla chrześcijan utrzymujących tę samą doktrynę Boga, lecz odrzucających darwinizm i akceptujących koncepcję specjalnego stworzenia. Chrześcijanin nie rozwiązuje bowiem problemu zła, zrzucając odpowiedzialność na naturalistyczny proces ewolucji (w tym wypadku — proces stworzony przez Boga). To jak zasypywanie jednego dołka tym, co wybrano przy kopaniu następnego.

Teistyczni ewolucjoniści odrzucają ten wniosek. Giberson, odnosząc się do mojej analogii do bandyty i agresywnego psa, zauważa:

Wkład, jaki teoria ewolucji wnosi do tej dyskusji [...] to zdumiewające odkrycie, że przyroda ma własne moce stwórcze. Jako chrześcijanie, wiemy, że te moce - między innymi moc stwarzania zarówno wspaniałych, jak i okropnych rzeczy — pochodzą od Boga, ale włada nimi przyroda. To tradycyjna koncepcja teologiczna przyjmująca, że Bóg działa zarówno za pomocą przyczyn wtórnych, jak i pierwotnych [...] dar kreatywności, jaką Bóg nadał stworzeniu, jest pod względem teologicznym analogiczny do daru wolności, jaką Bóg nadał nam. Zarówno my, jak $i$ stworzenie posiadamy wolność. Nasza wolność objawia się moralną odpowiedzialnością za właściwe jej wykorzystywanie. To jednak nie powstrzymuje nas przed robieniem okropnych rzeczy.

\footnotetext{
${ }^{21}$ Dokładnie na to wskazuje podtytuł książki Gibersona Saving Darwin, który brzmi: How to Be a Christian and Believe in Evolution [Jak być chrześcijaninem i wierzyć w ewolucję].
} 
Wolność nadaną ludziom przez Boga najjaskrawiej ukazuje fakt wybudowania komór gazowych w Oświęcimiu i Dachau. Ponieważ jednak ludzie mają wolność, nie mówimy, że to Bóg stworzył te komory gazowe. Bóg jest, by tak rzec, rozgrzeszony z tego zła. Dokładnie w taki sam sposób, pominąwszy wymiar moralny, gdy wolność przyrody prowadzi do wyewoluowania jakiejś bezwzględnej maszyny do zabijania, Bóg jest z tego „rozgrzeszony”. Jeżeli Bóg nie steruje przyrodą, co w przeciwnym razie pozbawiałoby ją autonomii, to coś takiego będzie się wydarzać. Podobnie, jeśli Bóg nie narzuca ludziom określonych decyzji, to często będziemy nadużywać swojej wolności. [...] Gdy Bóg nadaje wolność stworzeniom, oznacza to - co nierzadko trudno pojąć —że te stworzenia mogą działać niezależnie od Boga, że nie są mechanicznymi automatami lub wytresowanymi agresywnymi psami. W przypadku holokaustu zawsze robimy to, czego według Dembskiego nie robimy nigdy: zrzucamy odpowiedzialność z Boga na nazistów. Chrześcijanie od dawna snują takie refleksje na temat problemu zła. ${ }^{22}$

Giberson sugeruje, że dzięki ewolucji i związanej z nią wolności przyrody da się rozwiązać problemy dotyczące zła (zwłaszcza naturalnego), które już od tak dawna konfrontują klasyczny teizm z jego naukami o specjalnym stworzeniu. Argument Gibersona opiera się jednak na ekwiwokacji. Przypisywanie wolności ludziom stworzonym na obraz Boga to jedna sprawa. Nasza wolność pociąga za sobą odpowiedzialność moralną i zdolność dokonywania dobrowolnych wyborów. Byłyby one niemożliwe, gdyby nasze wybory były zdeterminowane pod każdym względem. Można zatem argumentować, że nawet wszechmogący Bóg musiał wybrać między stworzeniem wolnych i odpowiedzialnych istot a mocnym zdeterminowaniem, co mają one wybrać.

Jaką jednak odpowiedzialność moralną pociąga za sobą wolność przyrody? Jakich wyborów dokonuje gwiazda lub planeta? Czy ma jakikolwiek sens mówienie, że przyroda robi to, a powinna zrobić tamto? Giberson przyznaje, że przyroda jest wolna, ale z „pominięciem wymiaru moralnego”. Przyznanie tego sprawia jednak, że próba wykorzystania ewolucji do złagodzenia problemu zła skazana jest na zupełną klęskę. Przyroda po prostu robi to, co robi, i nie może obrać drogi samodoskonalenia, by robić to, co powinna robić. Ponadto to, co robi przyroda, ma związek ze zdolnościami, jakie nadał jej Bóg. Giberson mie-

\footnotetext{
${ }^{22}$ Karl Giberson, „Evolution and the Problem of Evil”, Beliefnet 28 September 2009, http:// blog.beliefnet.com/scienceandthesacred/2009/09/evolution-and-the-problem-of-evil.html $\quad(24.08$. 2013).
} 
sza ze sobą dwie skrajnie odmienne formy wolności. Jak w odpowiedzi Gibersonowi zauważył Clive Hayden:

Dlaczego Bóg miałby być rozgrzeszony ze stworzenia mechanizmu (ewolucji), który jest tak śmiercionośny i niszczycielski? W teodycei Gibersona Bóg nie tylko tworzy proces ewolucji, ale też wprowadza go do świata i uruchamia. To tak, jakbym ja wypuścił w mieście hordę myszy, których część zarażona jest dżumą. Myszy mają swoją wolność i mogą robić i iść, co i gdzie tylko zechcą, a przy tym ich postępowanie pozbawione jest „wymiaru moralnego”. Ten fakt $\mathrm{w}$ żaden jednak sposób nie „rozgrzesza" mnie, jeśli ktoś przez to umrze. ${ }^{23}$

Powoływanie się na wolność przyrody w celu złagodzenia problemu zła to długoletnia praktyka pośród teistycznych ewolucjonistów. John Polkinghorne, na przykład, dostrzega swoistą nieuchronność grzechu i zła, uznając je za konieczny koszt nadania przyrodzie wolności przez Boga. Godząc się z istnieniem zła naturalnego, Polkinghorne przytacza taką oto anegdotę:

Austin Farrer sam zadał sobie kiedyś pytanie, jaka była wola Boża w przypadku trzęsienia ziemi w Lizbonie (tego tragicznego kataklizmu w 1755 roku, który jednego dnia unicestwił 50000 istnień ludzkich). Farrer odpowiedział — a była to trudna, choć moim zdaniem prawdziwa odpowiedź - że Bóg chciał, aby elementy skorupy ziemskiej zachowywały się w zgodzie ze swoją naturą. Bóg nadał im wolność, tak samo jak obdarzył nią nas. ${ }^{24}$

Farrer prawdopodobnie tak samo wytłumaczyłby tsunami w Azji w 2004 i trzęsienie ziemi na Haiti w 2010 roku.

W każdym razie przywoływanie wolności przyrody nie przyczynia się zbytnio do rozwiązania problemów związanych z takimi przejawami zła. Możemy wyobrazić sobie świat znacznie brutalniejszy niż nasz, w którym kataklizmy powodują co roku śmierć wielu ludzi. Ewentualnie możemy wyobrazić sobie świat

\footnotetext{
${ }^{23}$ Clive HaYden, „,Karl Giberson Responds to William Dembski”, Uncommon Descent 29 September 2009, http://www.uncommondescent.com/evolution/karl-giberson-responds-to-dr-dem bski/ (24.08.2013).

${ }^{24}$ John Polkinghorne, „God's Action in the World”, J.K. Russell Fellowship Lecture 1990, http://www.starcourse.org/jcp/action.html (24.08.2013). Polkinghorne powtórzył tę anegdotę jesienią 2002 roku w ramach Parchman Lectures, sponsorowanych przez Seminarium Truetta w Baylor University (30 września i 1 października 2002).
} 
znacznie przyjaźniejszy niż nasz, w którym nikt nie umiera z powodu naturalnych kataklizmów, ponieważ jest to pogodny, tropikalny raj. Przypisywanie zła naturalnego wolności przyrody ani nie wyjaśnia ilości tegoż zła na świecie, ani nie wskazuje, czy wolność przyrody mogłaby przyjąć inną formę, pociągającą za sobą mniejszą ilość zła naturalnego (lub nawet całkowicie takie zło wykluczająca).

Czy trzęsienie ziemi w Lizbonie lub na Haiti naprawdę było jedynie konsekwencją wolności skorupy ziemskiej? Jak taka odpowiedź może pocieszyć ofiary lub ocalałych? Dlaczego, jak przed chwilą zauważyłem, Bóg po prostu nie umieścił nas na mniej niebezpiecznej planecie, na której trzęsienia ziemi nie odbierają ludziom życia? A może Bóg tego nie chciał, ale jeśli nie, to dlaczego? Jak mamy rozumieć Bożą opatrzność w świecie obdarzonym wolnością do zabijania nas? Dlaczego, jak w większości klasycznych liturgii kościołów chrześcijańskich, modlimy się o łagodne pory roku i obfite plony, jeśli wolność przyrody oznacza, że ziemia zrobi cokolwiek będzie chciała, bez względu na nasze modlitwy? A może Bóg ogranicza wolność przyrody? Ale jeżeli tak, to dlaczego Bóg nie nakłada większych ograniczeń na tę wolność, by zapobiec złu?

W wielu tych dyskusjach o wolności świata gubi się pewna ironia: jak wolność stworzenia, którą nadał mu swobodnie działający Bóg, może zmusić świat, aby był niebezpiecznym, pełnym zła miejscem? Czy wolność stworzenia nie powinna raczej dawać nam wolności, by nie grzeszyć? I czy Bóg nie powinien mieć możliwości stworzenia świata, którego wolność nie jest niszczycielska i nie pociąga za sobą zła? Jak na ironię, powoływanie się na wolność przyrody w próbie wyeliminowania problemu zła (naturalnego) wymaga, w kluczowych punktach, odmówienia Bogu wolności stwórczej.

Chociaż wielu teistycznych ewolucjonistów uznaje, że teoria Darwina pomaga rozwiązać problem zła, to wielu ewolucjonistów stojących na stanowisku agnostycyzmu i ateizmu uważa, że jest dokładnie przeciwnie. Jaki Bóg, pytają, stworzyłby życie za pomocą tak brutalnego i marnotrawnego procesu? Sam Darwin wciąż mówił o historii życia, że jest „wielkim bojem o życie” i „walką w przyrodzie”. ${ }^{25}$ Pisał on następująco: „Tak więc z walki w przyrodzie, z głodu

\footnotetext{
${ }^{25}$ Karol Darwin, $O$ powstawaniu gatunków drogą doboru naturalnego, czyli o utrzymywaniu się doskonalszych ras w walce o byt, tekst polski na podstawie przekładu Szymona Dickste-
} 
i śmierci bezpośrednio wynika najwznioślejsze zjawisko, jakie możemy pojąć, a mianowicie powstawanie wyższych form zwierzęcych". ${ }^{26}$ Walka o życie stanowi absolutnie centralny element jego teorii — właśnie tu kryje się stwórczy potencjał ewolucji.

Najsłynniejszą pracą Darwina jest O powstawaniu gatunków. Niewielu pamięta pełny jej tytuł: O powstawaniu gatunków drogą doboru naturalnego, czyli o utrzymywaniu się doskonalszych ras w walce o byt. Doskonalszych ras? Czyż nie oznacza to lepszych ras? I czy lepsze rasy nie implikują ras gorszych? W myśl teorii Darwina przeznaczeniem gorszych ras jest ich „wykorzenienie" i zniszczenie. W książce $\mathbf{O}$ pochodzeniu czlowieka, która stanowi kontynuację $\mathbf{O}$ powstawaniu gatunków, Darwin zauważył:

Wydaje się niemal pewne, że kiedyś w przyszłości, zresztą niedalekiej, bo mierzonej stuleciami, cywilizowane rasy ludzkie wytępią rasy dzikie, by zając ich miejsce na świecie. [...] Wtedy luka jeszcze się powiększy, ponieważ będzie się rozciągać między człowiekiem o wyższym stopniu cywilizacji, przypuszczalnie wyższym niż u przedstawicieli obecnej rasy kaukaskiej, a jakąś małpą tak nisko stojącą, jak np. pawian, zamiast, jak obecnie, pomiędzy Murzynem czy Australczykiem a gorylem. ${ }^{27}$

Tak więc Darwin nie miał wątpliwości - i uważał to za konsekwencję swojej teorii - że biali (których uznawał on za rasę „lepszą") wytępią czarnych (których postrzegał jako rasę ,gorszą"). Oczywiście nie cieszył się z tego, lecz traktował to jako naturalną konsekwencję swojego poglądu.

Chcąc złagodzić surowość ewolucji, teistyczny ewolucjonista Denis Alexander prosi nas, abyśmy wyobrazili sobie, że Bóg, stwarzając za pomocą procesów darwinowskich, jest jak ,wielki artysta w studio, pełen energii, kreatywny i rozpryskujący farbę we wszystkich kierunkach, z czego wyłania się bogactwo i różnorodność stworzonego porządku". ${ }^{28} \mathrm{Z}$ tej analogii do studia artysty nie wynika jednak, że kreatywność musi, jako naturalna konsekwencja, być niechlujna

ina i Józefa Nusbauma opracowały Joanna Popiołek i Małgorzata Yamazaki, Biblioteka Klasyków Nauki, Wydawnictwa Uniwersytetu Warszawskiego, Warszawa 2009, s. 72, 74, 118, 450.

\footnotetext{
${ }^{26}$ DARwin, O powstawaniu gatunków..., s. 450.

${ }^{27}$ Darwin, O pochodzeniu czlowieka..., s. 155-156.

${ }^{28}$ Alexander, Creation or Evolution..., s. 282.
} 
i marnotrawna. Byłem kiedyś marszandem (mój interes rodzinny polegał na kupowaniu i sprzedawaniu obrazów olejnych) i mogę zaświadczyć, że studia artystyczne mogą być całkiem czyste i ta czystość nie wpływa niekorzystnie na kreatywność artystów. Historia również nie świadczy o tym, że wielcy artyści najczęściej byli flejtuchami. A nawet gdyby, to i tak nie jest jasne, czym byłoby marnotrawstwo lub niechlujstwo dla wszechpotężnego Boga, dysponującego nieograniczonymi możliwościami. Dla celów argumentacji przyznajmy jednak, że Alexander słusznie nie obwinia Boga za jakiekolwiek możliwe marnotrawstwo lub niechlujstwo w procesie ewolucji.

Zarzut, że ewolucja jest ze swej natury okrutna, jeszcze bardziej utrudnia pogodzenie teizmu z teorią ewolucji. Niektórzy teoretycy próbowali złagodzić okrutność ewolucji, sugerując, że współpraca odgrywa w niej równie ważną rolę, jak rywalizacja. ${ }^{29}$ Jednak współpraca wcale nie eliminuje lub nie łagodzi okrutności przyrody, lecz stanowi jedynie jej skutek uboczny. Jest tak dlatego, ponieważ w kontekście darwinowskim organizmy podejmują współpracę wówczas, gdy inne organizmy z nimi rywalizują i starają się je unicestwić - innymi słowy, współpracują, gdy rywal jest dla nich okrutny. Okrucieństwo jakiejś grupy zewnętrznej jest, jak możemy powiedzieć, sposobem darwinowskiej ewolucji, by uczynić nas miłymi dla naszej własnej grupy. ${ }^{30}$

Ulubionymi sposobami, w jakie teistyczni ewolucjoniści radzą sobie z okrutnością przyrody, są zaprzeczanie i racjonalizacja. Dobór naturalny oczywiście pociąga za sobą ból, ale - jak podkreślał Darwin — jest to cena, którą warto zapłacić: „Ponieważ [...] dobór naturalny działa tylko dla dobra każdej żywej istoty, wszelkie dalsze cielesne i duchowe przymioty będą dążyć do doskonałości”. ${ }^{31}$ Darwin uświęcił więc ewolucję i ubóstwił dobór naturalny. To szkoda, że w historii naturalnej musi być tyle ofiar biorących się ,z walki w przyrodzie,

\footnotetext{
${ }^{29}$ Por. Robert Wright, Nonzero. Logika ludzkiego przeznaczenia, przeł. Zofia Łomnicka, Na Ścieżkach Nauki, Prószyński i S-ka, Warszawa 2005.

${ }^{30}$ Współpraca może też być podjęta przeciwko okrutności przyrody nieożywionej, na przy kład gdy grzyby i algi wspólnie produkują porosty, co stanowi pierwszy etap roślinnej kolonizacji ściany skalnej (por. Lynn Margulis and Dorion S Sagan, Acquiring Genomes: A Theory of the Origins of Species, Basic Books, New York 2002, s. 13-14).

${ }^{31}$ Darwin, O powstawaniu gatunków..., s. 449.
} 
z głodu i śmierci". ${ }^{32}$ Ale żeby zrobić omlet, trzeba rozbić kilka jaj, a ewolucja bez wątpienia wie, jak coś takiego robić.

Poza racjonalizacją jest też zaprzeczanie. Mówi się nam, że okrucieństwo nie jest naprawdę okrucieństwem, dopóki nie doświadczają go istoty moralne (takie jak my): „Podczas gdy okrutne szczury i złowrogie łasice mogą postępować niegodziwie na kartach książek dla dzieci”, pisze Denis Alexander, „to zgodnie z naszą najlepszą wiedzą prawdziwy świat zwierzęcy jest amoralny i nie obowiązuje w nim etyka". ${ }^{33}$ Alexander nie odróżnia tu jednak okrucieństwa jako świadomej motywacji (co w naszym przypadku jest karygodne, lecz inne zwierzęta takich motywacji nie mają) od okrucieństwa jako naszego doświadczenia (takiego okrucieństwa doświadczamy tak ze strony przyrody, jak w rezultacie złowrogich intencji innych ludzi). Słusznie uznajemy, że darwinowska interpretacja zapisu kopalnego - zgodnie z którą drapieżnictwo, parazytyzm, choroby, śmierć i wymieranie są stwórczymi mechanizmami życia ukazuje okrutność historii przyrody, mimo iż nie można powiedzieć, że zwierzęta mają okrutne motywacje.

Pojawiają się tu, rzecz jasna, różne niuanse. Coś może wydawać się okrutne z naszej perspektywy, lecz być postrzegane inaczej przez szczura. Wizja darwinowska przekształca jednak masową śmierć w rodzaj sub-stwórcy lub demiurga. Podejmuje problem śmierci i zła i zwiększa go wykładniczo. ${ }^{34}$

\footnotetext{
${ }^{32}$ Darwin, O powstawaniu gatunków..., s. 450.

${ }^{33}$ AleXander, Creation or Evolution..., s. 282.

${ }^{34} \mathrm{~W}$ przeciwieństwie do Darwina, który próbował zminimalizować okrutność ewolucji, niektórzy darwiniści robią sobie z tego rozrywkę. Weźmy choćby coroczne Nagrody Darwina. Według Wendy Northcutt, autorki książek dotyczących Nagród Darwina, przyznawane są one pośmiertnie osobom, które „dzięki swej głupocie przyczyniają się do przetrwania gatunku ludzkiego, eliminując z niego samych siebie" (cytat pochodzi z przedniej okładki jej książki: Wendy Northсuтt, Nagrody Darwina 2. Selekcja nienaturalna, przeł. Piotr Amsterdamski, Wydawnictwo W.A.B., Warszawa 2002). W swoich książkach Northcutt szczegółowo opisuje, przypadek po przypadku, pechową śmierć ludzi. To prawda, że okoliczności ich śmierci są zabawne. Nie znam jednak żadnego innego poglądu, religijnego czy świeckiego, który zachęcałby jego zwolenników do świętowania śmierci ludzi uznawanych przez nich za głupich. Dlaczego w nazwie tych nagród występuje nazwisko Darwina? Czyżby dlatego, że do nich pasuje? Czy ktokolwiek potrafi sobie wyobrazić, że w nazwie takich nagród widniałoby nazwisko Alberta Einsteina, Martina Luthera Kinga Jr. lub Michała Anioła?
} 
Oto moja konkluzja: problem zła stanowi trudne zagadnienie, lecz darwinowska teorii ewolucji, z Bogiem czy bez Niego, nie pomaga go ani trochę złagodzić.

William A. Dembski

\section{Death and the Fall:}

Why Theistic Evolution Does Nothing to Mitigate the Problem of Evil

\section{Summary}

Most theistic evolutionists increasingly argue that Christian theism benefits from the idea that God created indirectly by Darwinian means rather than directly (as in special creation). Theistic evolutionists worry that a God who creates directly renders the problem of evil insoluble. Such a God would be responsible for all the botched and malevolent designs we find in nature. By letting Darwinian natural selection serve as a designer substitute, theistic evolutionists can refer all those botched and malevolent designs to evolution. This, in their view, is supposed to resolve the problem of natural evil and thereby help validate Christian theism. They worry that a God who creates by direct intervention must be held accountable for all the bad designs in the world. Their proposed solution is therefore to have God set up a world in which evolution (by natural selection and random variation) brings about bad designs. But how does this address the underlying difficulty, which is that a creator God has set up the conditions under which bad designs emerge? In the one case, God acts directly; in the other, indirectly. But a Creator God, as the all-powerful source of all being, is

Nie tylko tradycyjni wyznawcy religijni wskazują na okrutność darwinowskiej ewolucji. Oto, co pisze przedstawicielka New Age, Lynne McTaggart:

Nasze wyobrażenie o sobie stało się jeszcze bardziej przygnębiające wraz z pracą Karola Darwina. Jego teoria ewolucji - nieco udoskonalona przez neodarwinistów — mówi o życiu, które jest losowe, drapieżne, pozbawione celu i samotne. Bądź najlepszy, albo nie przetrwasz. Jesteś wyłącznie ewolucyjnym przypadkiem. Ogromne, bogate dziedzictwo biologiczne twoich przodków zostało sprowadzone do jednego podstawowego aspektu: przetrwania. Jedz lub zostań zjedzony. Istotą twojej ludzkości jest terroryzm genetyczny, skuteczne pozbywanie się słabszych ogniw. W życiu nie chodzi o dzielenie się z innymi i współzależność, lecz o wygrywanie, bycie pierwszym. A jeśli uda ci się przetrwać, zostaniesz sam na szczycie ewolucyjnego drzewa.

Cytat pochodzi z: Lynne McTagGart, The Field: The Quest for the Secret Force of the Universe, updated edition, HarperCollins, New York 2008, s. xxiv-xxv. Takie przedstawienie sprawy jest oczywiście nieco karykaturalne. Tylko dlaczego teoria Darwina inspiruje takie karykatury? 
as responsible in the one case as in the other. For the Christian it does nothing to resolve the problem of evil by passing the buck to a naturalistic evolutionary process (a process, in that case, created by God). This is filling one hole by digging another. The problem of evil is a difficult issue, but Darwinian evolution, with or without God, does little to mitigate it.

Keywords: natural evil, cruelty, free will, moral responsibility, God, Christianity, Charles Darwin, Darwinism, theistic evolution, special creation.

Slowa kluczowe: zło naturalne, okrucieństwo, wolna wola, odpowiedzialność moralna, Bóg, chrześcijaństwo, Karol Darwin, darwinizm, teistyczny ewolucjonizm, koncepcja specjalnego stworzenia. 